\title{
Superstition, Family Planning, and Human Development*
}

\author{
Quy-Toan Do Dong Duc Phung $^{\ddagger}$
}

\begin{abstract}
Are "wanted" and "unwanted" children treated equally by their parents? To address this question, we rely on the observation that, according to Vietnamese astrology, dates of birth are believed to be determinants of success, luck, character and good match between individuals. We then examine fertility decisions made in Vietnam between 1976 and 1996 . We find that birth cohorts in auspicious years are significantly larger than in other years. Children born in auspicious years moreover do better both in health and education. While parental characteristics seem to affect fertility choices and human development simultaneously, our analysis suggests that family planning is one key mechanism leading to the observed differences in outcomes: in a society in which superstition is widespread, children born in auspicious years are more likely to have been planned by their parents, thus benefiting from more favorable financial, psychological, or emotional conditions for better human development.
\end{abstract}

Keywords: superstition, astrology, horoscope, fertility, education, health.

World Bank Policy Research Working Paper 4001, August 2006 (Revised September 2006).

The Policy Research Working Paper Series disseminates the findings of work in progress to encourage the exchange of ideas about development issues. An objective of the series is to get the findings out quickly, even if the presentations are less than fully polished. The papers carry the names of the authors and should be cited accordingly. The findings, interpretations, and conclusions expressed in this paper are entirely those of the authors. They do not necessarily represent the view of the World Bank, its Executive Directors, or the countries they represent. Policy Research Working Papers are available online at http://econ.worldbank.org.

${ }^{*}$ We would like to thank Harold Alderman, Jishnu Das, Monica Das Gupta, Do Ngoc Bach, Jed Friedman, Daniel Goodkind, Rema Hanna, Lakshmi Iyer, Ghazala Mansuri, Martin Rama, Biju Rao, Martin Ravallion, Klaus Rohland and Zurab Sajaya for helpful discussions. All remaining errors are ours.

${ }^{\dagger}$ Development Economics Research Group. The World Bank. Email: qdo@worldbank.org

${ }^{\ddagger}$ General Statistics Office. Government of Vietnam. Email: pdtung@gso.gov.vn 


\section{Introduction}

Are children born into the same family being treated equally? Most emphasis in the literature has been put either on gender preference (Thomas, 1994, Duflo, 2003), or birth order effects (Hauser and Sewell, 1985, Black et al., 2005). Another perspective taken on this issue consists of looking whether "wanted" or "unwanted" children receive equal attention from their parents. This question has been central to the literature on abortion regulation. Donohue and Levitt (2001) find that abortion legalization in the 1970s in the United States reduced crime levels in the 1990s. Similarly, Pop-Eleches (2006) documents that an abortion ban in Romania in 1966 induced a drop in average schooling achievement and labor market performance for children born after the ban. Yet, several channels may explain these findings. First, the marginal child - defined as the child who would be born in the absence of an abortion ban (Gruber et al., 1999) - might direclty affect other children of the same cohort because of crowding effects (Pop-Eleches, 2006). Second, the marginal child might be born into a family with lower socio-economic status (Gruber et al., 1999), or might induce his or her family to face adverse circumstances once born (Angrist and Evans, 1999). Finally, the marginal child might be penalized from not being wanted: parents might be less financially, psychologically or emotionally prepared to raise a child who has not been planned. ${ }^{1}$ While a great deal of effort has been made in order to disentangle these channels, the adopted empirical methodologies are severely limited. For by definition, the marginal child does not exist, so that the counterfactual is a child born into another family living in another state or time period with differing regulation vis-à-vis abortion. Therefore the question of the influence of parental unobservable characteristics on the marginal child's subsequent development remains unanswered. ${ }^{2}$

By adopting a different approach in a different context, our paper goes a long way towards addressing this issue. We build our empirical strategy on the observation that according to Vietnamese astrology, the year of birth of a child will determine his or her future prospects. A child born lucky is believed to have more chances to be healthy, able, or professionally successful. Superstitious parents

\footnotetext{
${ }^{1}$ The medical literature also emphasizes the effect of maternal distress during pregnancy on the risk of child's schizophrenia (Myhrman et al., 1996).

${ }^{2}$ Myhrman et al. (1995), Myhrman et al. (1996) look at outcomes of children whose mothers declared that the pregnancy was unwanted. David (1986) could observe children born to mothers that had requested an abortion twice but were denied. However, the empirical methodology adopted in all these studies compares two children in two different families, controlling for observable characteristics, so that outcomes of siblings in families concerned with unwanted pregnancies are not observed.
} 
who put emphasis on the quality of their offspring should then time birth following the horoscope. Consequently, Vietnamese children born in auspicious cohorts are more likely to have been the fruit of fertility planning. The marginal child in this context is then assimilated to the child born in a non-auspicious year. Family fixed-effect estimations allow us to make an even stronger case: by comparing siblings, we can control for any latent heterogeneity stemming from parental time-invariant characteristics.

For our empirical investigation, we use household surveys undertaken in Vietnam in 1992-93 and 1997-98 to compare birth cohorts across years. Years that are believed to bring good luck to either boys or girls have birth cohorts on average 7 percent larger than other years. Furthermore, sex ratios seem to follow the Vietnamese horoscope: in auspicious years for boys, there is an average of 106 boys for 100 girls, suggesting that the practice of astrology-driven sex-selective abortion might be taking place in Vietnam. When we turn to human development outcomes, we find that children born in these auspicious cohorts have higher levels of human development. While local or family-level characteristics might simultaneously affect the likelihood of having a child born in an auspicious year and his or her subsequent human development, explicitly controlling for these factors mildly affects the observed correlation between horoscope and health or education outcomes. Family fixed-effect estimations indicate that a child born in an auspicious year for either boys or girls has a body-massindex-for-age z-score 0.12 points higher, and will attend school an extra 0.36 years or 0.10 standard deviations more than his or her sibling born in an inauspicious year. Our results moreover suggest that better health outcomes are driven by improvements in weight rather than height. If familylevel time invariant characteristics cannot alone explain the observed differences, we are left with two competing mechanisms: it might be the case that children born lucky are either truly more fortunate, feel more confident by being told so, or receive more attention because their environment believes so (the "horoscope" effect); alternatively, children born in auspicious years might have parents that are then better prepared to raise them as they are the fruit of careful fertility planning. Using the fact that auspicious years differ across gender, and gender is not known by the time of the fertility decision, we disentangle these two channels and find strong evidence that fertility planning is an important determinant of subsequent human development: once controlling for the fertility planning, the "horoscope" effect is not significant, and the coefficient capturing the fertility-planning effect is almost unchanged. Furthermore, among children born unlucky because horoscope and gender do not match, those who are more likely to have been planned exhibit better health and educational outcomes later on. These results strongly suggest that children, in addition to gender and birth order 
effects, receive unequal treatment depending on whether they have been planned or not. Whether these differences are due to financial and psychological preparedness or to preferences remains an open question.

In addition to the aforementioned literature on child preference and abortion, our paper, by its cultural context, relates to the literature on religion and beliefs. Goodkind $(1991,1996)$ and Lee and Paik (2006) document how the horoscope can influence birth timing among Chinese and Korean families respectively. The former finds evidence of a "dragon-year baby boom" among the Chinese populations of South-East Asia, while the latter shows that Korean families avoid the inauspicious year of the horse to have children.

The paper is organized as follows: section 2 sketches the institutional framework underlying astrology and superstition in Vietnam. We look at reduced-form results in section 3. A discussion of the possible mechanisms underlying our findings is made in section 4, while section 5 tests the theory. Section 6 concludes.

\section{A Short Overview of Vietnamese Astrology}

In this section, we describe briefly the basis of Vietnamese astrology. ${ }^{3}$ To the connoisseur, this overview will surely look over-simplified. At the root of Vietnamese superstition is the Chinese "Y King" (4000 years B.C.) whereby the Universe found its origin from a unique entity and from such entity, emerged two states, Yin and Yang. Yang is as positive, masculine, left, high and tough as Yin is negative, feminine, right, low and soft. Around 200 years B.C., during the Han dynasty, a school of thought built a theory according to which the tension between Yin and Yang was related to the five elements: Metal, Wood, Water, Fire and Earth. During the Tsong dynasty (10th century A.D.), Chen Ruan made this theory into the "Fengshui", which, among other things, predicted the destiny of an individual based on her date of birth. A year is actually viewed as the association between a terrestrial appellation (Zhi) and a celestial prefix (Gan). There are 12 terrestrial appellations also known as zodiac animals (Rat, Ox, Tiger,...), while a celestial prefix is a combination of Yin or Yang and one of the five aforementioned elements, yielding a total of 10 prefixes. The 12 zodiac animals

\footnotetext{
${ }^{3}$ As Vietnamese astrology takes its root in Chinese astrology, names and references related to astrology will henceforth be in Chinese, with the exception of year names which are given in Vietnamese.
} 
are also in either Yin or Yang state. The Rat is Yang, while the Ox is Yin. As celestial prefixes and terrestrial appellations need to be in the same state (Yin or Yang), the Chinese and Vietnamese calendars are characterized by 60 -year cycles.

The horoscope is then determined depending on the compatibility between the gender of the newborn, and the celestial and terrestrial attributes of the year of birth. For example, a year characterized by Yin is on average more compatible with girls than with boys, while the reverse holds for Yang years. On top of that, there are compatibilities based on the elements. Table A1 in the appendix displays the horoscope for the entire 60-year cycle. To read this table, let's consider the top-left corner, "Canh Ty", which corresponds to year 1960 (modulo 60). That year is an inauspicious year for boys and neutral for girls. A one-year increment would then consist of moving one cell (modulo 10) to the right, and one cell (modulo 12) down. Table 1 shows for the time period we are interested in, which years are auspicious, inauspicious, or neutral for boys and girls respectively. A complete astral theme would also look at parents' dates and times of birth and their compatibility with their child's to refine the horoscope.

\section{Astrology, Fertility and Human Development Outcomes}

Most Vietnamese would acknowledge that they are superstitious, and that astrology significantly affects their daily decision-making. They would have a family fortune-teller whom they would consult before making important decisions. Having a child is one of them. However, whether this behavior translates into observed changes in patterns of birth that can be captured in nationally representative surveys is an open question. This section investigates whether astrology is associated with important decisions such as fertility choices, and how this translates into human development outcomes.

We therefore look at how fertility decisions are correlated with the Vietnamese horoscope. The main sources of data are the two rounds of the Vietnam Living Standards Measurement Study Survey undertaken in 1992-1993 and 1997-1998 respectively. We henceforth refer to these data sets

as VLSS93 and VLSS98, or VLSS more generically. Unless explicitly specified, we will use data from both surveys. VLSS are household surveys that cover topics ranging from health to education, labor activities and agricultural production, income and consumption, etc. The first wave consists of 4800 households while the second interviews 6000 households sampled across the country. Some 
households are interviewed in both rounds, but we will ignore the panel aspect and consider the two surveys as repeated cross-sections. We drop observations corresponding to children born during the survey years, as the timing of the survey would imply smaller observed cohorts in these years. Finally, due to the mismatch between lunar and solar calendars, years of birth have been re-computed so that say 1986 henceforth corresponds to the year of the Tiger (from February 9th, 1986 to January 29th, 1987). The year of birth of a child born in January 1986 will hence be coded 1985 .

Our empirical methodology is simple: we first check at whether birth cohorts are significantly larger in auspicious years, and then look at how human development outcomes correlate with the horoscope. We will focus solely on individuals born in and after 1976, as the country was at war in the previous years. Moreover, birth timing is believed to be a fairly recent phenomenon as concerns for child quality started becoming more pressing. Goodkind (1991), while looking at whether fertility decisions during the auspicious year of the Dragon concludes "that the Dragon Year was not a salient factor in Chinese fertility-timing decisions until 1976" (p. 666). Finally, in all regressions, unless specified otherwise, standard errors will be clustered at the year-of-birth level (see Bertrand et al., 2004).

\subsection{Astrology and Fertility Timing}

A first test of the effect of superstition consists of looking at whether the choice of the year of birth of children is driven by Vietnamese astrology:

$$
\ln N_{t}=a_{0}+a_{1} t+a_{2} t^{2}+c G_{t}+e_{t}
$$

in which $N_{t}$ is the national-level aggregate number of children born in year $t, G_{t}$ is the dummy variable that is equal to 1 if year $t$ is an auspicious year according to Vietnamese astrology, and 0 otherwise. $^{4}$

As discussed in Section 2, male are "Yang" and female are "Yin", so that horoscopes for boys and girls are likely to be different. We will thus adopt several specifications for variable $G_{t}$ : (i) whether year $t$ brings luck to boys, (ii) girls, (iii) both, or (iv) either. We will henceforth designate $G_{t}^{b}, G_{t}^{g}, G_{t}^{a n d}$, and $G_{t}^{o r}$ the dummy variables that are equal to 1 when year $t$ is auspicious for boys, girls, both and either respectively, and 0 otherwise. When $G_{t}=0$, year $t$ can be either neutral or

\footnotetext{
${ }^{4} N_{t}$ is computed by aggregating information from VLSS98 only.
} 
inauspicious. Given that the horoscope for boys differs than the one for girls, this leaves a large number of potential explanatory variables to look at. Our field work nevertheless suggests that in the case of Vietnam, parents care more about whether the year is auspicious or not, while they pay less attention to years considered as inauspicious. ${ }^{5}$

The results of the estimation of (1) are shown in Table 2 panel A. The first two columns show significantly larger cohort sizes in years that are auspicious for either boys or girls. The difference is estimated to be around 7 percent. This figure is of the same order of magnitude than earlier findings from Goodkind (1996) who finds between 12 and 22 percent increase in fertility during the years of the Dragon $(1976,1988)$ among Chinese households in Singapore. It moreover seems that the differences are mainly driven by years that are auspicious for boys. First, columns (1) and (2) give coefficients of similar magnitude, and second, columns (4) and (5) do not show any significant correlation between cohort size and horoscope for girls. Column (5) restricts the sample to years that are inauspicious for boys exclusively. Although the coefficient on the variable "auspicious for girls" is positive, it is not significant. We also tested for first and second order serial correlation, and could not reject the null hypothesis of no serial correlation of the error terms.

Graphically, the effect of astrology can be captured in Figure 1. The horizontal axis represents time. The smooth line predicts birth rates at the national level (predicted value of the regression of the logarithm of cohort size against a quadratic time trend), while the connected line shows actual country-level cohort sizes. We first notice a sharp fertility transition since the end of the 1980s, coinciding with the beginning of the "Doi Moi", or transition towards a market economy. The results found above indicate that most auspicious years (for boys, for girls, or both) are above the predicted line. Finally, if we add an extra observation corresponding to 1997 (column (6)), the results are similar to column (1), once we have readjusted cohort size and taken into account that 2 to 3 months have been truncated due to the timing of the survey.

Although Vietnamese, Chinese and Korean horoscope are similar, we can see graphically that Vietnamese data exhibit neither a "dragon-year baby boom" in 1976 or 1988, nor a "horse-year baby bust" in 1978 or 1990 contrary to the findings of Goodkind (1996) or Lee and Paik (2006). One reason for this, is that according to Vietnamese astrology, the year of the dragon is not systematically an

\footnotetext{
${ }^{5}$ Lee and Paik (2006) on the contrary find evidence that parents in South Korea tend to avoid having children in the inauspicious year of the horse.
} 
auspicious year; it is actually not so in our sample as shown in Table 1. Similarly, the year of the horse is not always bad omen either. Moreover, our field experience tends to suggest that Vietnamese people know little about astrology, but heavily rely on fortune-tellers when it comes to fertility timing. They are then likely to be advised according to the full horoscope rather than the sole zodiac animal as seems to be the case for Chinese or Korean populations.

\subsection{Astrology and Abortion}

If parents seem to deliberately choose auspicious years to have children, this requires the use of contraceptive methods. However, we do not have information on reproducive health in the VLSS, and even if we did, the information would be contemporaneous, hence of little interest to our analysis. Furthermore, reliable data on abortions are not available but for few recent years only. Nevertheless, using the fact that the horoscope generally differs for boys and girls, a theory of astrology-based fertility planning would predict sex-selective abortion which is correlated with the horoscope. Supersititious parents who planned to have a child in a year exclusively auspicious for boys (resp. girls), and who learn that they are expecting a girl (resp. boy), might want to terminate pregnancy.

To test this issue, we estimate (1), with $N_{t}$ being the national-level aggregate number of boys (resp. girls) born in year $t$. The results of the regressions are displayed in Table 2 panel B. The differences in patterns observed for boys and girls cohorts are suggestive of sex-selective abortion taking place. ${ }^{6}$ In the absence of sex-selective abortion, the patterns observed should be statistically indiguishable from the results in Table 2 panel A. Yet, we see that boys cohort sizes do strongly respond to astrology (columns (1) to (4)), while no significant effect is detected for girls (columns (5) to (8)). To formally test whether cohort sizes for boys and girls are equally affected by astrology, we estimate (1) with the logarithm of the sex ratio (number of boys divided by number of girls) on the left-hand side. Under the hypothesis of no astrology-related sex-selective abortion, the coefficient $c$ should be equal to zero. In addition to the common variables $G_{t}^{o r}, G_{t}^{b}$ and $G_{t}^{g}$, we look at the correlation with the variables $\left(G_{t}^{b}-G_{t}^{a n d}\right)$ and $\left(G_{t}^{g}-G_{t}^{a n d}\right)$ which are equal to 1 when year $t$ is a good year for boys (resp. girls) exclusively. If parents care about having a lucky year, the child needs to be born in an auspicious year and have the gender which enjoys the good omen that year.

\footnotetext{
${ }^{6}$ We omit from our argument the possibility that (i) parents have the ability to choose the gender of their child before pregnancy is started, and (ii) infanticide is a common practice.
} 
Astrology-based sex-selective abortion would predict that in years auspicious for boys only (resp. girls only), the sex ratio should be higher (resp. lower) than average, which in our case is equal to 1. Table 2 panel C shows the regression results which suggest that astrology-based sex-selective abortion is indeed taking place in Vietnam. In years auspicious for boys exclusively, there is an average of 107 boys for 100 girls (column (4)), while in years auspicious for girls exclusively, we on the other hand find that there is an average of 95 boys for 100 girls (column (7)). However, robustness checks suggest that the phenomenon observed for girls might capture a mean-reversion phenomenon: if boy-biased sex-selective abortion is taking place, then years in which no such practice is undertaken will mechanically exhibit a relatively lower sex ratio. This is even more important than horoscope for boys and girls tend to be negatively correlated. We therefore control for years that are not auspicious for boys only, and the measured effect drops significantly and ceases to be significant (column (8)).

The overall results presented so far suggest that broadly speaking fertility timing does follow Vietnamese astrology. A closer look indicates that astrology-based fertility decisions are potentially gender biased. First, the horoscope for boys is found to have a stronger effect on cohort sizes than the horoscope for girls does. This however may not necessarily mean that parents have a son preference. An alternative explanation lies in the relative frequencies of auspicious years for boys and for girls. While half of the years in our sample are auspicious for boys, less than a third are good omen for girls. It is then more costly to parents to time fertility according to girls' horoscope. Second, looking at patterns of sex ratios, we find compelling evidence that astrology-driven sex-selective abortion is taking place in Vietnam. Similarly, it seems that this practice is gender-biased in the sense that pregnancies might be terminated in years auspicious for boys only, when parents realize that they are expecting a girl. We do not find convincing evidence that the reverse holds in years auspicious for girls. As in the previous argument, the first explanation which comes to mind has to do with outright son preference. However, if the horoscope is not "binding" for girls, then we should not observe any sex-selective abortion in years auspicious for girls exclusively. Evidence obtained so far yet does not allow us to privilege one or the other channel.

\subsection{Astrology and Human Development: Preliminary Evidence}

The next step of the investigation consists of looking at children's human development outcomes, and see whether children born in better years actually have better prospects in life. Human development 
outcome indicators include the number of years of schooling the child completed by the time of the survey. Limited information on school performance does not allow us to assess the quality of education. As far as health is concerned, VLSS surveys include anthropometric information. From data on height and weight, we compute the body mass index (BMI) for each child. The BMI of an individual is the ratio between her weight (in $\mathrm{kg}$ ) and the square of her height (in $\mathrm{m}$ ). We then compute the z-scores for these anthropometric measures using the UK reference growth charts. The computation follows Cole (1990). The measures hence obtained are arguably comparable across gender and age groups; even though the reference group consists of British individuals, they apply to other countries as well (see Wagstaff et al., 2003 for an application to Vietnam). As expected, Vietnamese children are well below the UK average. They are more than two standard deviations below the UK reference average height and weight (see Table 3, panel A). The average BMI of our sample is also more than one standard deviation below UK reference group average. Although the construction of such scale was aimed at addressing the issue of childhood obesity in the UK (see Cole et al., 2000), these measures are also informative about the extent to which Vietnamese children are undernourished or malnourished (Wagstaff et al., 2003). Thus, in our sample, an increase in any of the aforementioned anthropometric measures will consistently indicate better health status on average. Table 3 shows the average weight, height, BMI and years of schooling for our sample population. Children in our sample are 12 years old on average, and are $1.3 \mathrm{~m}$ tall, weighing $29 \mathrm{~kg}$, with an average of 5 years in school.

We then estimate the following equation:

$$
Y_{i j}=a_{0}+a_{1} t_{i j}+a_{2} t_{i j}^{2}+c G_{i j}+X_{i j} b+e_{i j}
$$

in which $Y_{i j}$ is the outcome of interest (education and health) for child $i$ born in year $t_{i j}$ into family $j$, and $X_{i j}$ includes individual controls: $i$ 's gender and $i$ 's birth order. Our main specification consists of considering $G_{i j}^{o r}$, the dummy variable which is equal to 1 if child $i$ is born in a year auspicious for either boys or girls, and 0 otherwise. ${ }^{7}$

Table 4 panel A shows the result from the estimation of (2). We observe a statistically significant difference in human development between children born in auspicious years and those not. Whether we look at years of education or BMI-for-age, boys and girls born in these years considered to be auspicious for either boys or girls, perform better on average. The result on schooling (columns (2),

\footnotetext{
${ }^{7}$ Unless specified otherwise, auspicious years will henceforth refer to these years for which $G_{i t}^{o r}=1$.
} 
(6), and (10)) shows a positive effect of 0.13 standard deviations. This corresponds to a three month difference. Moving to health outcomes, even though children born in auspicious years exhibit larger BMI-for-age (up to 0.18 standard deviations for girls, column (9)), there is no conclusive evidence at this stage regarding what is driving the observed differences in BMI-for-age. The sign on the interaction between the horoscope of the year of birth and the child's birth order is consistently negative across specifications, but rarely significant.

\section{What are the Mechanisms at Work?}

We now review possible factors that have been omitted from equation (2) and which could plausibly drive the observed results.

\subsection{Commune-Level Determinants}

A first question to address relates to the environment into which children born in auspicious years belong. It might be the case that the extent of superstition in a community is positively correlated with some commune-level characteristics that are conducive to better human development outcomes for children. Communes in which the social norm is stronger or better enforced, could arguably be communes in which peer effects and role models are more pervasive. Parents are then more likely to follow the norm in terms of both superstition, and child care. On the other hand, time varying commune characteristics, such as the size of the cohort a child belongs to, can have a direct effect on his or her subsequent human development outcomes. In the case of cohort size, we would however expect such variable to have a negative effect on health and education. The literature on class size and school performance has promoted a congestion view, whereby larger class sizes make learning more difficult (see e.g. Angrist and Lavy, 1999). Peer effects on the other hand translate into a positive externality that a child can have on other children's learning or school attendance, and hence a positive relationship between cohort size and schooling. As far as health is concerned, the notion of congestion of health centers at time of birth comes to mind naturally, but one can think of reasons to believe that there might also be positive externalities: larger birth cohorts might receive 
better care if, for example, extra health personnel is mobilized. ${ }^{8}$

\subsection{Family-Level Characteristics}

Children born in auspicious years may be born in families with different characteristics. Superstitious parents who are more able or willing to invest in child care might also be able to time fertility according to the horoscope more carefully. Alternatively, parents who consult a fortune-teller to make their fertility decision might also be more open to third-party advice on child care and education. A direct effect of this is the number of siblings a child might have. If parents want to put an emphasis on quality rather than quantity of their offspring, choosing to have fewer children and timing fertility according to astrology are two instruments to achieve that end. Children born in auspicious years can also end up in smaller families when parents adopt some "lucky-child" stopping rules similar to the male-preferring stopping rules of Yamaguchi (1989). Thus, as in the case of son preference documented by Jensen (2002), children born lucky may have more parental resources to enjoy.

\subsection{Horoscope versus Fertility Planning}

When asking why differences in child outcomes arise, most people in Vietnam will answer in accordance with their degree of superstition. The answer could very well be that children born lucky might indeed be privileged by Nature. Alternatively, parents believing that children born lucky have better innate ability will invest more, provided that ability and investment are complement. Finally, children learning from their environment that they are born under a lucky star might be more self-confident. While this might not translate into better health, self-confidence at early ages can arguably have an impact on schooling and subsequently on the labor market (see Persico et al., 2004).

An alternative rationale relies on the fertility planning argument made earlier on. Superstitious parents plan to have children during auspicious years, and one consequence of such careful planning is financial, psychological, and emotional readiness. Thus, what matters in determining human development outcomes is ex-ante preparedness rather than ex-post luck. Children born in lucky

\footnotetext{
${ }^{8}$ Note that in order to get a convex relationship between cohort size and health care quality, lumpiness of investments (personnel, infrastructure, assets) needs to be assumed.
} 
years grow in a more privileged environment.

As opposed to the discussion made previously, differences in outcomes are here driven by familylevel time-varying rather than time-invariant characteristics.

\section{Empirical Results}

We now test the hypotheses discussed in the previous section. We look at a specific class of variables that can be omitted when estimating equation (2); these are commune-level or family-level determinants. First, superstition can be a community-wide feature, and at the same time be associated with other social norms affecting human development. Second, parental characteristics can drive both fertility timing and child care. And third, the number of children in a household can be driven by parental superstitious behavior, but might also directly affect human development outcomes, independently of parental characteristics. We investigate empirical evidence on these three issues in turn.

\subsection{Characterizing the "Superstitious" Family}

It is not possible to directly measure the degree of superstition with our current survey instrument. We will instead look at outcomes, i.e. whether the first child of a family is born in an auspicious year. By doing so, we capture both willingness and ability to time birth, rather than the only extent of superstition.

\subsubsection{What Parents are Superstitious?}

We want to see whether the propensity to be superstitious is correlated with socio-economic determinants. To assess, though imperfectly, a family's level of superstition, we observe the year of birth of the first child. A family will therefore be considered as superstitious if and only if the first child is born in an auspicious year. We then estimate the following linear probability model:

$$
F_{j}=\alpha+\beta X_{j}+\varepsilon_{j}
$$


where $F_{j}$ is a dummy variable equal to 1 if the first child in family $j$ is born in an auspicious year, and 0 otherwise; $X_{j}$ is a vector of parental (and commune-level) characteristics. Table 5 panel A shows the results from the estimation of (3). ${ }^{9}$ We find that when parents are older, the first child is relatively less likely to be born in an auspicious year for either boys or girls, or just for boys (columns (1) and (5)). This is consistent with the idea that older parents have less time ahead of them to choose the year of birth of their first child. More interestingly, we find that when mothers are more educated and fathers are less so, then the first child is more likely to be born in an auspicious year. The effect is not significant for fathers' education in the simplest specifications (columns (2) and (6)) but holds when we control for family per-capita expenditure (columns (4) and (8)). While other mechanisms could explain these findings, the results are consistent with the commonly-shared view in Vietnam that among parents, women are the ones who are superstitious. The signs of the coefficients on mother's and father's education then reflect the extent of relative bargaining power in the household when it comes to, among other things, fertility decision. ${ }^{10}$ Surprisingly, no effect of real per capita expenditure is detected (columns (3) and (7)).

\subsubsection{Astrology and Family Size}

We push the analysis further by looking at how superstition correlates with family size. To test whether the channels discussed in section 4 can be detected in the data, we propose the following model:

$$
H_{j}=a+c F_{j}+X_{j} b+e_{j},
$$

in which $H_{j}$ is family $j^{\prime} s$ number of children, and $F_{j}$ is the dummy which is equal to 1 if the first child in family $j$ is born in an auspicious year. Note that family will refer to the nuclear household (parents and children), while household refers to the more standard survey definition. To test the first channel described above, $F_{j}$ will be the dummy variable which equals 1 if the first child in family $j$ is born in a year auspicious for either boys or girls $\left(G^{o r}=1\right)$, or alternatively lucky for boys $\left(G^{b}=1\right)$. For the second channel, $F_{j}$ will be equal to 1 if and only if the first child in family $j$, is born lucky, i.e. she is a girl born in a year auspicious for girls, or he is a boy born in a year auspicious for boys.

\footnotetext{
${ }^{9}$ We also ran probit specifications, without any noticeable differences.

${ }^{10}$ An alternative explanation is the more educated women are more able to control fertility. However such argument could not at the same time explain the negative effect of fathers' education.
} 
The results of the estimation of (4) are shown in Table 5 panel B. Columns (1) to (4) test the first channel, while columns (5) and (6) look for evidence of a "lucky-child" preference. All the results do not lend support to the mechanisms which might relate superstition to household size, although the coefficients on $F_{j}$ are consistently negative across various specifications. In the results presented in Table 5, standard errors were clustered at the family level. The correlation with other covariates (parents' age at time of first birth, or parents' education) are as expected: when parents are older when the first child is born, they end up having fewer children; educated parents have fewer children as well. Finally, not surprisingly either given Vietnam's known son preference, when the first child is a boy, the family ends up being smaller in size.

\subsection{Fertility Planning and Human Development}

We have documented in the previous section the fact that parental characteristics might be related with the willingness or ability to time birth according to Vietnamese astrology. To what extent do these characteristics drive the observed differences shown in section 3? We address this issue next.

\subsubsection{Astrology and Human Development: Further Evidence}

We include household, parental and commune-level controls in the estimation of (2). The results in Table 4 panel B are qualitatively similar to the estimates provided in panel A. Although parents' background might affect their behavior, observable characteristics do not essentially drive the observed positive correlation between astrology and human development outcomes.

To control for latent heterogeneity, we also run family-level fixed effect regressions. The results are presented in Table 4, panel C. The results are consistent with the ones presented previously. Children born in an auspicious year will achieve higher levels of schooling than their siblings born in non-auspicious years (column (2)). As far as health is concerned, the result is similar: BMI-for-age will be larger for children born in auspicious years, compared to their "unlucky" siblings (column (1)). Under family fixed-effect specifications, the interaction term between horoscope and birth order is negative and significant (columns (1) and (2)), suggesting that the effect is stronger for first children. Finally, the results presented in columns (3) and (4), suggest that the observed better 
health is mostly driven by weight (column (4)) rather than height (column (3)). ${ }^{11}$

\subsubsection{Superstition, Fertility and Human Development}

Results gathered so far suggest that commune-level and family-level time-invariant characteristics could not alone explain the differences in human development outcomes between children of auspicious and inauspicious cohorts. We are thus left with two remaining channels that call for family-level time-varying factors: (i) the "horoscope" channel, versus (ii) the "fertility planning" channel.

In order to disentangle these two channels, we combine the fact that gender of the future child is not known when fertility decision is made, with a feature of Vietnamese astrology that auspicious years for boys usually differ from auspicious years for girls. We can then see whether ex-ante planning or ex-post horoscope matter for subsequent human development outcomes. If the horoscope is the driving force behind our results, then a boy must be born in an auspicious year for boys, and a girl must be born in an auspicious year for girls in order to be privileged. On the other hand, in the family-planning scenario, irrespectively of gender, being born in an auspicious year for either boys or girls is the only thing which matters. We thus construct the variable born-lucky defined by $g_{i j}=$ gender $_{i j} G_{i j}^{b}+\left(1-\right.$ gender $\left._{i j}\right) G_{i j}^{g}$, where gender $_{i j}$ is equal to 1 if $i$ (in family $j$ ) is a boy, and 0 otherwise and estimate equation (2) with both variables $G_{i j}^{o r}$ and $g_{i j}$ on the right-hand side. Results are presented in Table 6, panel A. ${ }^{12}$ The results on the overall sample (columns (1) and (2)), suggest that most difference in health and education are driven by fertility planning rather than the horoscope. However, when separating our sample by gender, our results are affected by the fact that auspicious years for either boys or girls, and auspicious for boys are highly correlated (.75), and that, as also suggested previously, fertility decision might be driven solely by how auspicious to boys a year is. To address this issue further, we isolate from our sample children not privileged according to the horoscope: either boys born in years that are not auspicious years for boys, or girls born in years not auspicious for girls. In Figure 2 panel A, we can see what the two hypotheses would predict. Under the "horoscope" hypothesis, boys born in auspicious years for girls, and girls born in auspicious years for boys (shaded areas) would have the same outcomes than children born in non-auspicious years

\footnotetext{
${ }^{11}$ It is worth noting that the fixed-effect estimation leaves out single-child families (2528 cases out of 8240 ), and families for which there is no variation on the horoscope of the year of birth. Thus, the sample drops from 8240 families down to 4411.

${ }^{12}$ Family fixed-effect estimations show similar results and are not shown here.
} 
(dotted areas). However, under the "fertility planning" hypothesis, the former would exhibit higher levels of human development than the latter would. Table 6 panel B shows consistent results that among these unlucky children, those who were born in a year auspicious for either boys or girls are doing better than otherwise; even though the horoscope is not favorable to these children, being the fruit of fertility planning translates into better subsequent human development. These results confirm our presumption that fertility planning might play a role in explaining the differences in human development across birth cohorts. Finally, under the hypothesis that astrology-based fertility planning concerns boys only, we restrict further our sample to girls only: we compare girls born lucky in a year inauspicious for boys (shaded areas in Figure 2 panel B), with girls born unlucky in a year auspicious for boys (dotted areas). The regression results are showed in Table 6, panel C. The result for education suggests that for girls, being born in an auspicious year for boys matters beyond and above the actual ex-post horoscope.

\subsection{Who is the "Marginal Child"? A Tale of Child Preference and its Implication for Targeting}

The conclusions drawn from the analysis above complements the findings of the earlier litterature, which primarily dealt with the issue of abortion. The analyses of the impact of abortion regulation usually find evidence that the marginal child is worse off when abortion is banned. The reasons often invoked either refer to the socio-economic situation of the parents of the marginal child, or to general equilibrium effects.

Our analysis yet suggests a different story: children who are the outcome of fertility planning are better taken care of. We find evidence of planned-child preference: parents can or want to take better care of children who have been planned. The finding that there are within-family inequalities potentially has implications for how one wants to implement social programs aimed at children. An interpretation of our findings is that targeting based on parental characteristics might not be sufficient to reach the child who needs it most. A child born to parents above the poverty line can well qualify as poor, vice and versa. If female stipend programs are well-suited to address the issue of male preference (see Khandker et al., 2003), they crucially (and implictly) rely on the fact that gender is observable. On the other hand, "being-planned" is not a salient feature, which makes contingent policies not implementable. 
In our context, we can nevertheless try to characterize families for which planned-child preference is binding. We estimate (2) with family fixed-effects and interaction terms. Table 7 displays the regression results. We considered both hypotheses that astrology-based fertility might and might not be boy-biased. It is worth noting that larger families are more prone to have a planned-child preference as far as health outcomes are concerned (columns (1) and (5)). This result is fairly intuitive as larger families are more likely to have unplanned children, and resources per child are scarcer. An unexpected finding is the positive and significant coefficient on the interaction between the astrology variables and expenditure (columns (2) and (6)). It is all the more interesting than planned-child preference among the rich seems to be driving the observed differences in schooling. Finally, birth order and gender do not seem to affect parental child preference as far as education is concerned. However, when it comes to health outcomes, we see an effect of gender on both height and weight, translating to a negative effect on the BMI.

This preliminary analysis sheds some light on the patterns of child preference among Vietnamese families. The results do not allow for definitive conclusions. There is some evidence of gender and birth order affecting parental planned-child preference, and it also seems that child preference is stronger among wealthier parents. On the latter point, when it comes to targeting, the question is now to determine who to prioritize: the "marginal child" in the "average family", or the "average child" in the "marginal family"? Targeting based on child characteristics could be an option; social programs with a within-family redistributive property or a familiy-level public good component might also go a long way towards mitigating the potential within-family inequality documented in this paper.

\section{Conclusion}

Superstition in Vietnam seems pervasive. Years that might bring luck to girls or boys have birth cohorts 7 percent larger on average than other years. We find that overall, being born in these years increases BMI-to-age z-score by 0.12 points, and years of schooling by almost 4 months or 0.12 standard deviations. Family fixed-effects estimations deliver comparable results, which induces us to claim that such differences are due to a fertility planning effect: parents who have planned their child have more favorable financial, psychological or emotional conditions to invest in his or her future human development. 
One question however remains: what explains the persistence of superstition? If persistence of superstitious beliefs is driven by observational data, why don't parents factor out the effects described in the paper? One reason relates to informational cascades and herding (see e.g. Banerjee, 1992, Welch, 1992). If, for any reason, caring parents all have children born in auspicious years, then there is no counterfactual to disentangle the impacts of nature versus nurture, or in other words, lucky-birth effects from fertility planning effects. Thus information stops flowing, and no updating takes place. Steady-state beliefs can well put a positive probability on the fact that being born lucky does improve human development. An alternative explanation is discussed in Anderson (1988), who revisits the arguments of Adam Smith regarding religious participation. Those could apply in the context of superstition in Vietnam: superstitious beliefs could in part be seen as signaling devices for parents trying to build reputation for being good parents. They then hope to adhere to a social network of other good parents, so that their children can grow among other well-educated children. Empirical evidence supporting these mechanisms is an independent research agenda. 


\section{References}

[1] Anderson, G., "Mr. Smith and the Preachers: The Economics of Religion in the Wealth of Nations", Journal of Political Economy, 96(5): 1066-88. 1988.

[2] Angrist, J., and V. Lavy, "Using Maimonides' Rule to Estimate the Effect of Class Size on Student Achievement", Quarterly Journal of Economics, 114(2): 533-75. 1999.

[3] Banerjee, A., "A Simple Model of Herd Behavior", Quarterly Journal of Economics, 107(3): 797-818. 1992

[4] Bertrand, M., E. Duflo, and S. Mullainathan, "How Should We Trust Difference-in-Differences Estimates?", Quarterly Journal of Economics, 119(1): 249-75. 2004

[5] Black, S., P. Devereux and K. Salvanes, "The More the Merrier? The Effect of Family Size and Birth Order on Children's Education", Quarterly Journal of Economics, 120(2): 669-701. 2003.

[6] Cole, T., "The LMS method for constructing normalized growth standards", European Journal of Clinical Nutrition, 44: 45-60. 1990.

[7] Cole, T., M. Bellizzi, K. Flegal, and W. Dietz, "Establishing a standard definition for child overweight and obesity worldwide: international survey." British Medical Journal, 320(7244): 1240-3. 2000.

[8] David, H., "Unwanted Children: A Follow-Up from Prague", Family Planning Perspectives, 18(3): 143-44. 1986.

[9] Donohue, J., and S. Levitt, "The Impact of Legalized Abortion on Crime", Quarterly Journal of Economics, 116(2): 379-420. 2001.

[10] Duflo, E., "Grandmothers and Granddaughters: Old-Age Pensions and Intrahousehold Allocation in South Africa", World Bank Economic Review, 17(1): 1-25. 2003.

[11] Goodkind, D., "Creating New Traditions in Modern Chinese Populations: Aiming for Birth in the Year of the Dragon", Population and Development Review, 17(4): 663-86. 1991.

[12] Goodkind, D., "Chinese Lunar Birth Timing in Singapore: New Concerns for Child Quality Amidst Multicultural Modernity", Journal of Marriage and the Family, 58(3): 784-95. 1996. 
[13] Gruber, J., P. Levine, and D. Staiger, "Abortion Legalization and Child Living Circumstances: Who is the "Marginal Child"?", Quarterly Journal of Economics, 114(1), 263-92. 1999

[14] Hauser, R. and W. Sewell, "Birth Order and Educational Attainment in Full Sigships", American Educational Research Journal, 22: 1-23. 1985.

[15] Jensen, R., "Equal Treatment, Unequal Outcomes? Generating Sex Inequality Through Fertility Behavior", mimeo Harvard University. 2002.

[16] Khandker, S., M. Pitt, and N. Fuwa, "Subsidy to Promote Girls' Secondary Education: The Female Stipend in Bangladesh", mimeo 2003.

[17] Lee, J., and M. Paik, "Sex preferences and Fertility in South Korea during the Year of the Horse", Demography, 43(2). 2006.

[18] Myhrman, A., P. Olsen, P. Rantakallio, and E. Laara, "Does the Wantedness of a Pregnancy Predict a Child's Educational Attainement?", Family Planning Perspectives, 27(3): 116-19. 1995.

[19] Myhrman, A., P. Rantakallio, M. Isohanni, P. Jones, and U. Partanen, "Unwantedness of a Pregnancy and Schizophrenia in the Child", British Journal of Psychiatry, 169: 637-40. 1996.

[20] Persico, N., A. Postlewaite, and D. Silverman, "The Effect of Adolescent Experience on Labor Market Outcomes: The Case of Height", Journal of Political Economy, 112(5): 1019-53.

[21] Pop-Eleches, C. "The Impact of an Abortion Ban on Socioeconomic Outcomes of Children: Evidence from Romania", Journal of Political Economy, 114(4): 744-73. 2006.

[22] Thomas, D., "Like Father, Like Son; Like Mother, Like Daughter. Parental Resources and Child Height", Journal of Human Resources, 29(4): 950-88. 1994.

[23] Wagstaff, A., E. van Doorslaer, and N. Watanabe, "On decomposing the causes of health sector inequalities with an application to malnutrition inequalities in Vietnam", Journal of Econometrics, 112(1): 207-223. 2003.

[24] Welch, I., "Sequential Sales, Learning and Cascades", Journal of Finance, 47(2): 695-732. 1992.

[25] Yamaguchi, K. "A Formal Theory for Male-Preferring Stopping Rules of Child-Bearing: Sex Differences in Birth Order and in the Number of Siblings," Demography, 26(3): 451-65. 1989. 
Figure 1: Superstition and Fertility: 1976-1996

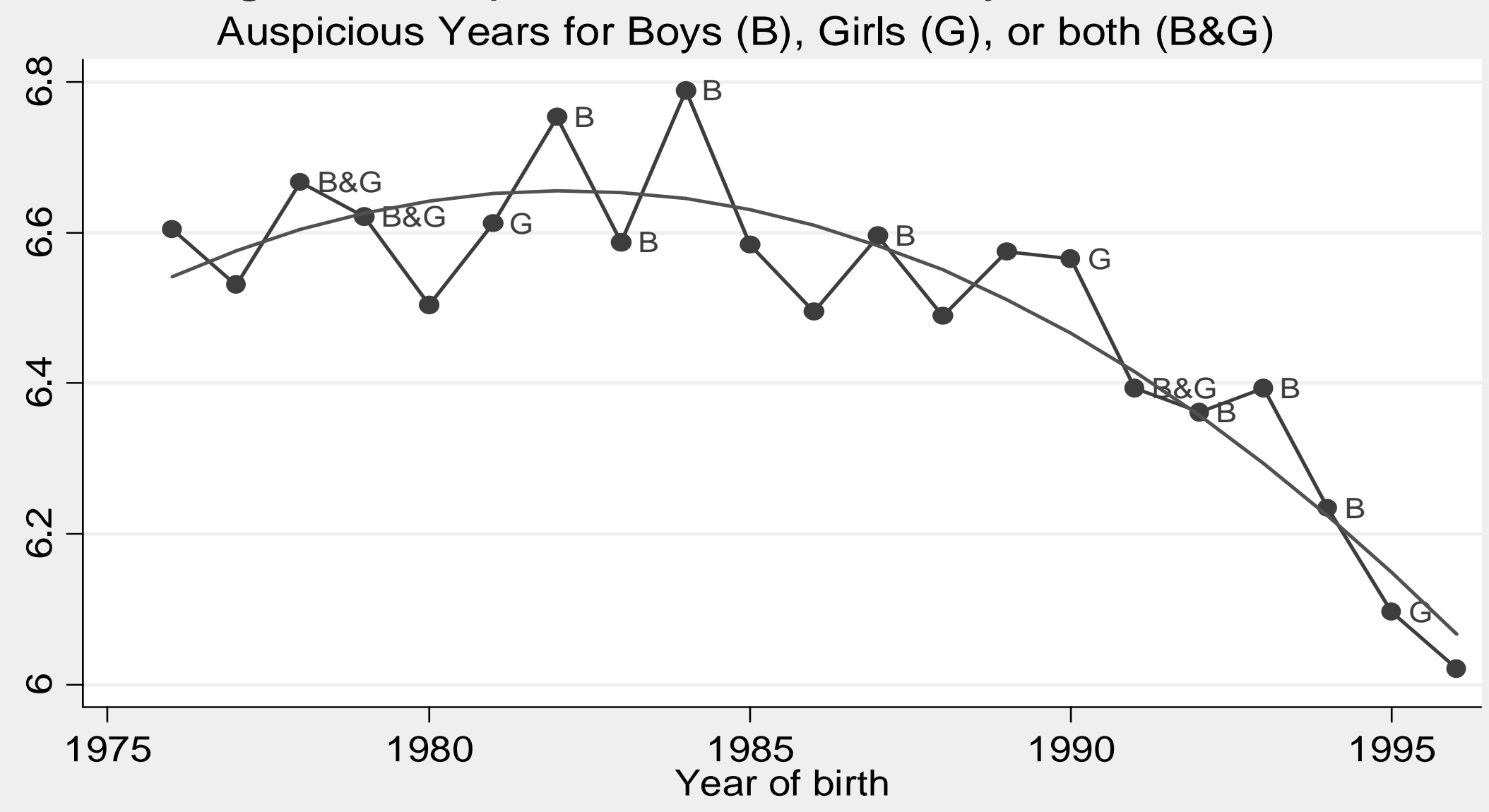

$\longrightarrow \log$ of cohort size predicted log of cohort size 
Figure 2: Astrology and Human development outcomes: theoretical predictions

PANEL A: Horoscope versus Family Planning

\begin{tabular}{|c|c|c|c|}
\hline \multicolumn{4}{|c|}{ Horoscope hypothesis } \\
\hline & Auspicious year for boys & Auspicious year for girls & Non-auspicious year \\
\hline Boys & + & & 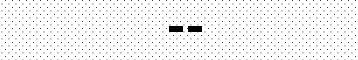 \\
\hline Girls & & + & 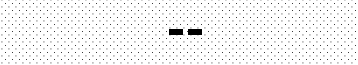 \\
\hline \multicolumn{4}{|c|}{ Family planning hypothesis } \\
\hline & Auspicious year for boys & Auspicious year for girls & Non-auspicious year \\
\hline Boys & + & W & 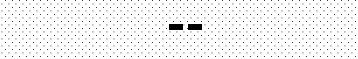 \\
\hline Girls & - & + & 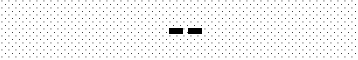 \\
\hline
\end{tabular}

PANEL B: Male-biased Horoscope versus Family Planning

\begin{tabular}{|c|c|c|c|}
\hline \multicolumn{4}{|c|}{ Male-biased horoscope hypothesis } \\
\hline & Auspicious year for boys & Auspicious year for girls & Non-auspicious year \\
\hline Girls & & + & -- \\
\hline \multicolumn{4}{|c|}{ Family planning hypothesis } \\
\hline & Auspicious year for boys & Auspicious year for girls & Non-auspicious year \\
\hline Girls & - & -- & -- \\
\hline
\end{tabular}


Table 1: Vietnames horoscope 1975-1997

\begin{tabular}{|c|c|c|c|}
\hline Birth year & Name of year* & Boy & Girl \\
\hline 1975 & At Mao & Bad luck & Neutral \\
\hline 1976 & Binh Thin & Neutral & Bad luck \\
\hline 1977 & Dinh Ty & Neutral & Bad luck \\
\hline 1978 & Mau Ngo & Good luck & Good luck \\
\hline 1979 & Ky Mui & Good luck & Good luck \\
\hline 1980 & Canh Than & Bad luck & Bad luck \\
\hline 1981 & Tan Dau & Neutral & Good luck \\
\hline 1982 & Nham Tuat & Good luck & Bad luck \\
\hline 1983 & Quy Hoi & Good luck & Neutral \\
\hline 1984 & Giap Ty & Good luck & Bad luck \\
\hline 1985 & At Suu & Bad luck & Bad luck \\
\hline 1986 & Binh Dan & Neutral & Bad luck \\
\hline 1987 & Dinh Mao & Good luck & Bad luck \\
\hline 1988 & Mau Thin & Neutral & Neutral \\
\hline 1989 & Ky Ty & Bad luck & Neutral \\
\hline 1990 & Canh Ngo & Neutral & Good luck \\
\hline 1991 & Tan Mui & Good luck & Good luck \\
\hline 1992 & Nham Than & Good luck & Bad luck \\
\hline 1993 & Quy Dau & Good luck & Bad luck \\
\hline 1994 & Giap Tuat & Good luck & Neutral \\
\hline 1995 & At Hoi & Neutral & Good luck \\
\hline 1996 & Binh Ty & Neutral & Neutral \\
\hline 1997 & Dinh Suu & Good luck & Bad luck \\
\hline
\end{tabular}

* Name of year is given in Vietnamese

Data source: see Table A1 


\section{Table 2: Birth cohort sizes and horoscope (1976-1996)}

\section{PANEL A: Overall sample}

\begin{tabular}{|c|c|c|c|c|c|c|}
\hline \multirow[b]{2}{*}{ Independent variables } & \multicolumn{6}{|c|}{ Dependent variable: Logarithm of birth cohort size } \\
\hline & $(1)$ & $(2)$ & (3) & $(4)$ & (5) & $(6)$ \\
\hline Year auspicious for either boys or girls (1:yes,0:no) & $\begin{array}{l}0.070^{\star \star} \\
{[0.033]}\end{array}$ & & & & & $\begin{array}{l}0.071^{\star *} \\
{[0.032]}\end{array}$ \\
\hline Year auspicious for boys (1:yes,0:no) & & $\begin{array}{l}0.064^{*} \\
{[0.033]}\end{array}$ & & & & \\
\hline Year auspicious for both boys and girls (1:yes,0:no) & & & $\begin{array}{c}0.015 \\
{[0.034]}\end{array}$ & & & \\
\hline Year auspicious for girls (1:yes,0:no) & & & & $\begin{array}{c}0.009 \\
{[0.034]}\end{array}$ & $\begin{array}{c}0.048 \\
{[0.040]}\end{array}$ & \\
\hline Year of birth & $\begin{array}{c}11.760^{\star \star *} \\
{[1.872]}\end{array}$ & $\begin{array}{c}11.663^{\star * *} \\
{[1.813]}\end{array}$ & $\begin{array}{c}12.301^{* * *} \\
{[1.974]}\end{array}$ & $\begin{array}{c}12.291^{\star * \star} \\
{[1.970]}\end{array}$ & $\begin{array}{c}11.192^{\star \star \star} \\
{[2.218]}\end{array}$ & $\begin{array}{c}11.493^{\star * *} \\
{[1.682]}\end{array}$ \\
\hline Year of birth squared & $\begin{array}{c}-0.003^{\star \star *} \\
{[0.000]}\end{array}$ & $\begin{array}{c}-0.003^{\star * *} \\
{[0.000]}\end{array}$ & $\begin{array}{c}-0.003^{\star * \star} \\
{[0.000]}\end{array}$ & $\begin{array}{c}-0.003^{\star \star \star} \\
{[0.000]}\end{array}$ & $\begin{array}{c}-0.003^{\star * *} \\
{[0.001]}\end{array}$ & $\begin{array}{c}-0.003^{\star \star \star} \\
{[0.000]}\end{array}$ \\
\hline Observations & 21 & 21 & 21 & 21 & 14 & 22 \\
\hline R-squared & 0.88 & 0.88 & 0.85 & 0.85 & 0.89 & 0.91 \\
\hline Durbin-Watson d-statistics & 2.13 & 2.18 & 2.29 & 2.29 & 1.22 & 2.12 \\
\hline Durbin test of 2nd order serial correlation: Chi2 (Prob>Chi2) & $0.66(0.72)$ & $1.44(0.49)$ & $1.84(0.40)$ & $1.59(0.45)$ & $0.70(0.71)$ & $0.72(0.70)$ \\
\hline
\end{tabular}

Data: VLSS98 only.

Robust standard errors in parenthesis

* significant at $10 \%$; ** significant at $5 \%$; ${ }^{* * *}$ significant at $1 \%$

Column (5): restricted to years that are inauspicious for boys exclusively

Column (6): includes adjusted 1997 birth cohort 


\section{PANEL B: Boys vs Girls cohorts}

\begin{tabular}{|c|c|c|c|c|c|c|c|c|c|c|}
\hline \multirow[b]{2}{*}{ Independent variables } & \multicolumn{5}{|c|}{ Dependent variable: Logarithm of boys cohort size } & \multicolumn{5}{|c|}{ Dependent variable: Logarithm of girls cohort size } \\
\hline & (1) & (2) & (3) & (4) & (5) & (6) & $(7)$ & (8) & (9) & (10) \\
\hline Year auspicious for either boys or girls (1:yes,0:no) & $\begin{array}{l}0.090^{\star *} \\
{[0.036]}\end{array}$ & & & & & $\begin{array}{c}0.051 \\
{[0.041]}\end{array}$ & & & & \\
\hline Year auspicious for boys ( $1: y e s, 0: n o)$ & & $\begin{array}{l}0.093^{* *} \\
{[0.037]}\end{array}$ & & & & & $\begin{array}{c}0.035 \\
{[0.037]}\end{array}$ & & & \\
\hline Year auspicious for boys exclusively ( $1: y e s, 0:$ no) & & & $\begin{array}{l}0.105^{\star *} \\
{[0.042]}\end{array}$ & & & & & $\begin{array}{c}0.034 \\
{[0.041]}\end{array}$ & & \\
\hline Year auspicious for girls (1:yes, $0:$ no) & & & & $\begin{array}{l}-0.003 \\
{[0.041]}\end{array}$ & & & & & $\begin{array}{c}0.024 \\
{[0.035]}\end{array}$ & \\
\hline Year auspicious for girls exclusively (1:yes, $0:$ no) & & & & & $\begin{array}{c}-0.021 \\
{[0.051]}\end{array}$ & & & & & $\begin{array}{c}0.025 \\
{[0.045]}\end{array}$ \\
\hline Time trend (linear, quadratic) & yes & yes & yes & yes & yes & yes & yes & yes & yes & yes \\
\hline Observations & 21 & 21 & 21 & 21 & 21 & 21 & 21 & 21 & 21 & 21 \\
\hline R-squared & 0.83 & 0.84 & 0.84 & 0.78 & 0.78 & 0.88 & 0.87 & 0.87 & 0.86 & 0.86 \\
\hline Durbin-Watson d-statistics & 2.21 & 2.46 & 2.51 & 2.45 & 2.50 & 2.00 & 1.93 & 1.93 & 2.10 & 2.11 \\
\hline Durbin test of 2nd order serial correlation: $\mathrm{Chi} 2$ (Prob>Chi2) & $1.24(0.53)$ & $2.93(0.23)$ & $3.33(0.19)$ & $4.35(0.11)$ & $5.05(0.08)$ & $0.08(0.96)$ & $0.27(0.87)$ & $0.09(0.96)$ & $0.14(0.93)$ & $0.09(0.95)$ \\
\hline
\end{tabular}

Durbin test of 2nd order serial correlation: Chi2 (Prob>Chi2)

$1.24(0.53) \quad 2.93(0.23) \quad 3.33(0.19) \quad 4.35(0.11)$

\begin{tabular}{l|l}
$5.05(0.08)$ & $0.08(0.96)$ \\
\hline
\end{tabular}

$27(0.87)$

$.09(0.96)$

Robust standard errors in parenthesis

* significant at $10 \%$; ${ }^{* *}$ significant at $5 \%$; ${ }^{* *}$ significant at $1 \%$

\section{PANEL C: Sex ratios}

\begin{tabular}{|c|c|c|c|c|c|c|c|c|}
\hline \multirow[b]{3}{*}{ Independent variables } & \multicolumn{8}{|c|}{ Dependent variable: Logarithm of sex ratio } \\
\hline & & & & mean (s. & $.00(.10)$ & & & \\
\hline & (1) & (2) & (3) & (4) & (5) & (6) & (7) & (8) \\
\hline Year auspicious for either boys or girls (1:yes,0:no) & $\begin{array}{c}0.042 \\
{[0.040]}\end{array}$ & & & & & & & \\
\hline Year auspicious for boys (1:yes,0:no) & & $\begin{array}{l}0.062^{*} \\
{[0.032]}\end{array}$ & $\begin{array}{c}0.063^{*} \\
{[0.032]}\end{array}$ & & & & & \\
\hline Year auspicious for boys exclusively (1:yes, $0:$ no) & & & & $\begin{array}{l}0.074^{* *} \\
{[0.030]}\end{array}$ & $\begin{array}{c}0.076^{*} \\
{[0.043]}\end{array}$ & & & $\begin{array}{c}0.069^{*} \\
{[0.038]}\end{array}$ \\
\hline Year auspicious for girls (1:yes,0:no) & & & $\begin{array}{c}-0.032 \\
{[0.032]}\end{array}$ & & $\begin{array}{c}0.004 \\
{[0.043]}\end{array}$ & $\begin{array}{c}-0.032 \\
{[0.034]}\end{array}$ & & \\
\hline Year auspicious for girls exclusively (1:yes, $0:$ no) & & & & & & & $\begin{array}{l}-0.052^{* *} \\
{[0.021]}\end{array}$ & $\begin{array}{l}-0.018 \\
{[0.032]}\end{array}$ \\
\hline
\end{tabular}

Time trend (linear, quadratic)

Observations

R-squared

$\begin{array}{ccc}\text { yes } & \text { yes } & \text { yes } \\ 22 & 22 & 0.58\end{array}$

Durbin-Watson d-statistics

$\begin{array}{ccc}22 & 22 & 22 \\ 0.51 & 0.56 & 0.58\end{array}$

Durbin test of 2nd order serial correlation: Chi2 (Prob>Chi2)

2.06

$2.37 \quad 2.71$

yes yes

Data: VLSS98 only.

Robust standard errors in parenthesis

* significant at $10 \%$; ** significant at $5 \%$; ${ }^{* * *}$ significant at $1 \%$ 


\section{TABLE 3: Summary statistics}

\begin{tabular}{lccc} 
Variable & Observations & Mean & St. Dev \\
\hline Born in an auspicious year for either boys or girls (1:yes,0:no) & 22386 & 0.60 & 0.49 \\
Born in an auspicious year for boys (1:yes,0:no) & 22386 & 0.46 & 0.50 \\
Born in an auspicious year for girls (1:yes,0:no) & 22386 & 0.27 & 0.45 \\
Born in an auspicious year for both boys and girls (1:yes,0:no) & 23836 & 0.15 & 0.35 \\
Gender (1:boy,0:girl) & 23836 & 0.50 & 0.50 \\
Age & 23836 & 12.69 & 5.98 \\
Height (cm) & 21652 & 130.22 & 24.79 \\
Weight (kg) & 21653 & 29.61 & 14.02 \\
Body Mass Index (kg/m^2) & 21652 & 16.25 & 2.63 \\
Height for age (z-score) & 21652 & -2.10 & 1.14 \\
Weight for age (z-score) & 21653 & -2.30 & 1.16 \\
Body Mass Index for age (z-score) & 21587 & -1.21 & 1.01 \\
Education level (years) & 20320 & 5.08 & 3.42 \\
Per capita real expenditure ('000 VND) & 23836 & 2394.07 & 1929.24 \\
Number of children per (nuclear) family & 23836 & 3.35 & 1.62 \\
Birth order & 23836 & 2.15 & 1.30 \\
Mother's age at first birth & 22520 & 27.70 & 6.33 \\
Father's age at first birth & 20704 & 30.33 & 7.25 \\
Mother's education level (years) & 21811 & 6.40 & 3.29 \\
Father's education level (years) & 22216 & 7.44 & 3.34 \\
Mother's height (cm) & 22247 & 151.80 & 4.97 \\
Father's height (cm) & 19955 & 161.76 & 5.71 \\
Mother's weight (kg) & 22248 & 46.42 & 6.95 \\
Father's weight (kg) & 19957 & 52.04 & 6.79 \\
\hline Data:VS93 and VLSS98. & & \\
\hline
\end{tabular}

Data:VLSS93 and VLSS98. 


\section{Table 4: Astrology and Human Development}

\section{PANEL A: Reduced-form outcomes}

\begin{tabular}{|c|c|c|c|c|c|c|c|c|c|c|c|}
\hline \multicolumn{4}{|c|}{ Overall sample } & \multicolumn{4}{|c|}{ Boys only } & \multicolumn{4}{|c|}{ Girls only } \\
\hline $\begin{array}{c}\text { BMl for age } \\
\text { z-score } \\
\text { (1) }\end{array}$ & $\begin{array}{c}\text { Schooling } \\
\text { (years) } \\
(2)\end{array}$ & $\begin{array}{c}\text { Weight for } \\
\text { age z-score } \\
\text { (3) }\end{array}$ & $\begin{array}{c}\text { Height for } \\
\text { age z-score } \\
(4)\end{array}$ & $\begin{array}{c}\text { BMI for age } \\
\text { z-score } \\
(5) \\
\end{array}$ & $\begin{array}{c}\text { Schooling } \\
\text { (years) } \\
(6)\end{array}$ & $\begin{array}{c}\text { Weight for } \\
\text { age z-score } \\
(7)\end{array}$ & $\begin{array}{c}\text { Height for } \\
\text { age z-score } \\
(8)\end{array}$ & $\begin{array}{c}\text { BMl for age } \\
\text { z-score } \\
(9)\end{array}$ & $\begin{array}{c}\text { Schooling } \\
\text { (years) } \\
(10)\end{array}$ & $\begin{array}{c}\text { Weight for } \\
\text { age z-score } \\
\text { (11) }\end{array}$ & $\begin{array}{c}\text { Height for } \\
\text { age } z \text {-score } \\
(12)\end{array}$ \\
\hline $0.149^{\star \star}$ & $0.609^{\star \star}$ & $0.111^{*}$ & 0.046 & $0.102^{*}$ & $0.700^{\star \star}$ & $0.128^{\star}$ & 0.042 & $0.193^{\star \star}$ & $0.520^{\star \star}$ & 0.091 & 0.050 \\
\hline$[0.055]$ & {$[0.214]$} & [0.053] & [0.071] & {$[0.055]$} & {$[0.246]$} & {$[0.063]$} & [0.103] & {$[0.075]$} & [0.205] & [0.071] & {$[0.060]$} \\
\hline-0.008 & -0.074 & -0.028 & -0.034 & -0.010 & -0.085 & -0.019 & -0.020 & -0.006 & -0.063 & $-0.037^{*}$ & $-0.049^{* \star *}$ \\
\hline$[0.019]$ & [0.053] & {$[0.017]$} & [0.021] & {$[0.021]$} & {$[0.057]$} & {$[0.027]$} & {$[0.034]$} & {$[0.026]$} & {$[0.061]$} & {$[0.019]$} & {$[0.016]$} \\
\hline-0.062 & -0.017 & $-0.201^{\star \star \star}$ & $-0.114^{\star \star \star}$ & & & & & & & & \\
\hline$[0.046]$ & {$[0.045]$} & {$[0.057]$} & {$[0.033]$} & & & & & & & & \\
\hline 0.017 & -0.016 & 0.004 & -0.007 & 0.014 & -0.025 & -0.005 & -0.014 & 0.020 & -0.005 & 0.014 & -0.001 \\
\hline$[0.016]$ & [0.044] & {$[0.013]$} & {$[0.020]$} & {$[0.017]$} & {$[0.050]$} & {$[0.021]$} & {$[0.033]$} & {$[0.020]$} & {$[0.048]$} & {$[0.014]$} & {$[0.010]$} \\
\hline$-14.871^{\star * *}$ & $68.456^{\star \star \star}$ & -2.052 & -1.595 & $-10.799^{\star \star *}$ & $67.827^{\star \star \star}$ & $5.502^{*}$ & 2.006 & $-19.011^{\star \star \star}$ & $69.397^{\star * *}$ & $-9.722^{\star * *}$ & $-5.244^{*}$ \\
\hline [2.612] & [17.926] & {$[2.366]$} & [2.220] & {$[2.074]$} & [18.685] & [2.719] & [2.306] & [3.624] & [17.775] & [2.970] & [2.559] \\
\hline $0.004^{\star \star *}$ & $-0.017^{\star \star \star}$ & 0.001 & 0.000 & $0.003^{\star * *}$ & $-0.017^{\star \star *}$ & $-0.001^{*}$ & -0.001 & $0.005^{\star \star *}$ & $-0.018^{\star \star \star}$ & $0.002^{\star \star \star}$ & $0.001^{*}$ \\
\hline$[0.001]$ & {$[0.005]$} & {$[0.001]$} & {$[0.001]$} & {$[0.001]$} & {$[0.005]$} & {$[0.001]$} & {$[0.001]$} & {$[0.001]$} & {$[0.004]$} & {$[0.001]$} & {$[0.001]$} \\
\hline 20804 & 19435 & 20870 & 20869 & 10558 & 9922 & 10590 & 10590 & 10246 & 9513 & 10280 & 10279 \\
\hline 0.02 & 0.48 & 0.01 & 0.01 & 0.02 & 0.49 & 0.01 & 0.01 & 0.03 & 0.47 & 0.01 & 0.00 \\
\hline
\end{tabular}

Number of observations

\begin{tabular}{lc} 
Independent variables & $(1)$ \\
\hline Child is born in an auspicious year (1:yes,0:no) & $0.149^{\star \star}$ \\
& {$[0.055]$} \\
Interaction "auspicious-year" dummy with birth order & -0.008 \\
& {$[0.019]$} \\
Child's gender (1:male;0:female) & -0.062 \\
& {$[0.046]$} \\
Child's birth order & 0.017 \\
& {$[0.016]$} \\
Year of birth & $-14.871^{\star \star *}$ \\
& {$[2.612]$} \\
Year of birth squared & $0.004^{\star \star *}$ \\
& {$[0.001]$} \\
& \\
Number of observations & 20804 \\
R squared & 0.02 \\
\hline Data:VLSS93 and VLSS98 & \\
Robust standard errors in brackets, clustered at the year-of-birth leve \\
${ }^{\star}$ significant at $10 \% ;{ }^{* \star}$ significant at $5 \% ;{ }^{* * *}$ significant at $1 \%$ \\
An auspicious year is a year that is lucky for either boys or girls
\end{tabular}

An auspicious year is a year that is lucky for either boys or girls 
PANEL B: Controlling for parental characteristics

\begin{tabular}{|c|c|c|c|c|c|c|}
\hline & \multirow{2}{*}{\multicolumn{2}{|c|}{ Overall sample }} & & & & \\
\hline & & & \multicolumn{2}{|c|}{ Boys only } & \multicolumn{2}{|c|}{ Girls only } \\
\hline & $\begin{array}{c}\text { BMl for age } \\
\text { z-score } \\
\text { (1) }\end{array}$ & $\begin{array}{c}\text { Schooling } \\
\text { (years) } \\
(2)\end{array}$ & $\begin{array}{l}\text { BMl for age } \\
\text { z-score } \\
\text { (3) }\end{array}$ & $\begin{array}{c}\text { Schooling } \\
\text { (years) } \\
(4)\end{array}$ & $\begin{array}{l}\text { BMl for age } \\
\text { z-score } \\
(5)\end{array}$ & $\begin{array}{c}\text { Schooling } \\
\text { (years) } \\
(6)\end{array}$ \\
\hline \multirow[t]{2}{*}{ Child is born in an auspicious year (1:yes, $0: n o)$} & $0.148^{* *}$ & $0.472^{* \star *}$ & 0.097 & $0.655^{\star \star \star}$ & $0.188^{* *}$ & $0.276^{\star}$ \\
\hline & {$[0.058]$} & {$[0.136]$} & {$[0.060]$} & {$[0.165]$} & {$[0.083]$} & {$[0.156]$} \\
\hline \multirow[t]{2}{*}{ Interaction "auspicious-year" dummy with child's birth order } & -0.011 & $-0.067^{\star *}$ & -0.014 & $-0.116^{\star \star}$ & -0.008 & -0.012 \\
\hline & {$[0.020]$} & {$[0.029]$} & {$[0.025]$} & {$[0.047]$} & {$[0.027]$} & {$[0.035]$} \\
\hline \multirow[t]{2}{*}{ Child's gender ( 1 :male;0:female) } & -0.039 & -0.04 & & & & \\
\hline & [0.045] & {$[0.046]$} & & & & \\
\hline \multirow{2}{*}{ Child's birth order } & 0.015 & -0.022 & -0.016 & -0.009 & $0.050^{*}$ & -0.051 \\
\hline & {$[0.021]$} & {$[0.054]$} & {$[0.029]$} & {$[0.059]$} & {$[0.026]$} & {$[0.059]$} \\
\hline \multirow[t]{2}{*}{ Logarithm of commune cohort size } & 0.017 & $0.350^{\star \star \star}$ & 0.003 & $0.358^{\star \star *}$ & 0.04 & $0.369^{* * *}$ \\
\hline & {$[0.018]$} & {$[0.043]$} & {$[0.017]$} & {$[0.055]$} & {$[0.026]$} & {$[0.065]$} \\
\hline \multirow[t]{2}{*}{ Logarithm of real per capita expenditure } & -0.083 & $2.185^{\star * *}$ & -0.08 & $2.227^{\star \star \star}$ & -0.082 & $2.117^{* * *}$ \\
\hline & {$[0.052]$} & {$[0.177]$} & {$[0.052]$} & {$[0.183]$} & {$[0.065]$} & {$[0.174]$} \\
\hline \multirow[t]{2}{*}{ Family's number of children } & -0.016 & $0.085^{\star}$ & 0.002 & $0.113^{\star *}$ & $-0.034^{*}$ & 0.072 \\
\hline & {$[0.016]$} & {$[0.045]$} & {$[0.017]$} & {$[0.044]$} & {$[0.020]$} & {$[0.055]$} \\
\hline \multirow[t]{2}{*}{ Father's BMI $\left(\mathrm{kg} / \mathrm{m}^{\wedge} 2\right)$} & $0.090^{\star \star \star}$ & -0.003 & $0.087^{\star \star \star}$ & -0.014 & $0.095^{\star \star \star}$ & 0.007 \\
\hline & {$[0.006]$} & {$[0.009]$} & {$[0.007]$} & {$[0.017]$} & {$[0.006]$} & {$[0.009]$} \\
\hline \multirow[t]{2}{*}{ Mother's BMI (kg/m^2) } & $0.077^{\star \star \star}$ & $-0.029^{\star *}$ & $0.075^{\star \star \star}$ & $-0.032^{\star \star}$ & $0.078^{\star \star *}$ & $-0.023^{*}$ \\
\hline & {$[0.005]$} & {$[0.007]$} & {$[0.007]$} & {$[0.012]$} & {$[0.008]$} & {$[0.011]$} \\
\hline \multirow[t]{2}{*}{ Father's education level } & 0 & $0.044^{\star \star}$ & 0.001 & $0.046^{\star \star \star}$ & -0.004 & $0.040^{\star *}$ \\
\hline & {$[0.003]$} & {$[0.015]$} & {$[0.004]$} & {$[0.013]$} & {$[0.004]$} & {$[0.019]$} \\
\hline \multirow[t]{2}{*}{ Mother's education level } & -0.003 & $0.086^{\star * *}$ & -0.007 & $0.090^{\star * \star}$ & 0.003 & $0.085^{\star * *}$ \\
\hline & {$[0.004]$} & {$[0.015]$} & {$[0.005]$} & {$[0.017]$} & {$[0.005]$} & {$[0.017]$} \\
\hline \multirow[t]{2}{*}{ Mother's age at birth of first child } & $0.005^{\star *}$ & $0.013^{* * *}$ & 0.006 & $0.019^{\star \star *}$ & 0.005 & 0.01 \\
\hline & {$[0.003]$} & {$[0.004]$} & {$[0.004]$} & {$[0.006]$} & {$[0.004]$} & {$[0.007]$} \\
\hline \multirow[t]{2}{*}{ Father's age at birth of first child } & -0.002 & 0.012 & 0.005 & 0.006 & $-0.009^{*}$ & 0.016 \\
\hline & {$[0.003]$} & {$[0.007]$} & {$[0.004]$} & {$[0.008]$} & {$[0.004]$} & {$[0.011]$} \\
\hline Time trend (linear and quadratic) & yes & yes & yes & yes & yes & yes \\
\hline Commune fixed-effects & yes & yes & yes & yes & yes & yes \\
\hline Number of observations & 15601 & 14731 & 8068 & 7642 & 7533 & 7089 \\
\hline R squared & 0.16 & 0.71 & 0.19 & 0.72 & 0.2 & 0.71 \\
\hline
\end{tabular}

\section{Data:VLSS93 and VLSS98}

Robust standard errors in brackets, clustered at the year-of-birth level

${ }^{*}$ significant at $10 \% ;{ }^{* *}$ significant at $5 \%$; ${ }^{* * *}$ significant at $1 \%$

An auspicious year is a year that is auspicious for either boys or girls 


\section{PANEL C: Family fixed-effects}

\begin{tabular}{|c|c|c|c|c|}
\hline \multirow[b]{2}{*}{ Independent variables } & \multicolumn{4}{|c|}{ Dependent variables } \\
\hline & $\begin{array}{l}\text { BMI for age } \\
\text { z-score } \\
\text { (1) }\end{array}$ & $\begin{array}{c}\text { Schooling } \\
\text { (years) } \\
(2) \\
\end{array}$ & $\begin{array}{c}\text { Height for age } \\
\text { z-score } \\
\text { (3) }\end{array}$ & $\begin{array}{c}\text { Weight for age } \\
\text { z-score } \\
(4)\end{array}$ \\
\hline Child is born in an auspicious year (1:yes, $0:$ no) & $\begin{array}{c}0.177^{\star * *} \\
{[0.037]}\end{array}$ & $\begin{array}{c}0.402^{* * *} \\
{[0.072]}\end{array}$ & $\begin{array}{l}-0.015 \\
{[0.040]}\end{array}$ & $\begin{array}{l}0.091^{* *} \\
{[0.039]}\end{array}$ \\
\hline Interaction "Auspicious-year" dummy with child's birth order & $\begin{array}{l}-0.021^{*} \\
{[0.012]}\end{array}$ & $\begin{array}{l}-0.055^{\star *} \\
{[0.025]}\end{array}$ & $\begin{array}{c}-0.02 \\
{[0.017]}\end{array}$ & $\begin{array}{l}-0.026^{*} \\
{[0.015]}\end{array}$ \\
\hline Child's gender ( 1 :male;0:female) & $\begin{array}{c}-0.052^{* * *} \\
{[0.017]}\end{array}$ & $\begin{array}{c}0.041 \\
{[0.036]}\end{array}$ & $\begin{array}{c}-0.083^{* * *} \\
{[0.018]}\end{array}$ & $\begin{array}{c}-0.166^{\star * *} \\
{[0.019]}\end{array}$ \\
\hline Child's birth order & $\begin{array}{c}-0.02 \\
{[0.021]}\end{array}$ & $\begin{array}{c}0.042 \\
{[0.050]}\end{array}$ & $\begin{array}{c}-0.168^{\star \star \star} \\
{[0.026]}\end{array}$ & $\begin{array}{c}-0.158^{\star * *} \\
{[0.026]}\end{array}$ \\
\hline Time trend (linear, quadratic) & yes & yes & yes & yes \\
\hline Family fixed-effects & yes & yes & yes & yes \\
\hline Number of observations & 20804 & 19435 & 20869 & 20870 \\
\hline R squared & 0.63 & 0.89 & 0.69 & 0.66 \\
\hline
\end{tabular}

Data:VLSS93 and VLSS98

Robust standard errors in brackets, clustered at the commune level

* significant at $10 \%$; ${ }^{* *}$ significant at $5 \%$; ${ }^{* *}$ significant at $1 \%$

An auspicious year is a year that is auspicious for either boys or girls 


\section{Table 5: Characterizing "Superstitious" families}

PANEL A: Determinants of superstitious behavior: Linear probability model

\begin{tabular}{|c|c|c|c|c|c|c|c|c|}
\hline \multirow[b]{2}{*}{ Independent variables } & \multicolumn{4}{|c|}{$\begin{array}{c}\text { Dependent variable: First child is born } \\
\text { in auspicious year for either boys or girls (1:yes,0:no) }\end{array}$} & \multicolumn{4}{|c|}{$\begin{array}{l}\text { Dependent variable: First child is born } \\
\text { in auspicious year for boys (1:yes, } 0: n o)\end{array}$} \\
\hline & (1) & $(2)$ & (3) & $(4)$ & (5) & $(6)$ & $(7)$ & $(8)$ \\
\hline Mother's age at time of first birth & $\begin{array}{l}-0.011^{* * *} \\
{[0.003]}\end{array}$ & & & $\begin{array}{l}-0.008^{* *} \\
{[0.003]}\end{array}$ & $\begin{array}{c}-0.010^{* * *} \\
{[0.003]}\end{array}$ & & & $\begin{array}{l}-0.007^{\star} \\
{[0.004]}\end{array}$ \\
\hline Father's age at time of first birth & $\begin{array}{l}-0.004^{*} \\
{[0.002]}\end{array}$ & & & $\begin{array}{l}-0.007^{* *} \\
{[0.003]}\end{array}$ & $\begin{array}{l}-0.001 \\
{[0.002]}\end{array}$ & & & $\begin{array}{l}-0.004 \\
{[0.003]}\end{array}$ \\
\hline Mother's education & & $\begin{array}{l}0.023^{* \star *} \\
{[0.003]}\end{array}$ & & $\begin{array}{l}0.019^{* * *} \\
{[0.004]}\end{array}$ & & $\begin{array}{l}0.014^{* * *} \\
{[0.003]}\end{array}$ & & $\begin{array}{l}0.012^{\star \star \star} \\
{[0.004]}\end{array}$ \\
\hline Father's education & & $\begin{array}{l}-0.003 \\
{[0.003]}\end{array}$ & & $\begin{array}{l}-0.011^{* *} \\
{[0.004]}\end{array}$ & & $\begin{array}{l}-0.002 \\
{[0.003]}\end{array}$ & & $\begin{array}{l}-0.009^{* *} \\
{[0.004]}\end{array}$ \\
\hline Logarithm of per capita real expenditure & & & $\begin{array}{c}-0.002 \\
{[0.012]}\end{array}$ & $\begin{array}{l}-0.035 \\
{[0.026]}\end{array}$ & & & $\begin{array}{c}0.008 \\
{[0.012]}\end{array}$ & $\begin{array}{c}-0.022 \\
{[0.026]}\end{array}$ \\
\hline Commune fixed-effects & no & no & no & yes & no & no & no & yes \\
\hline Observations & 3983 & 4236 & 5239 & 3383 & 3983 & 4236 & 5239 & 3383 \\
\hline R-squared & 0.03 & 0.02 & 0.00 & 0.14 & 0.01 & 0.01 & 0.00 & 0.11 \\
\hline
\end{tabular}

\section{Data:VLSS93 and VLSS98}

Robust standard errors in brackets, clustered at the commune level

* significant at $10 \%$; ${ }^{* *}$ significant at $5 \%$; ${ }^{* * *}$ significant at $1 \%$ 


\section{PANEL B: Determinants of Family Demographics}

\begin{tabular}{|c|c|c|c|c|c|c|}
\hline \multirow{2}{*}{ Independent variables } & \multicolumn{6}{|c|}{ Dependent variable: Number of children in family } \\
\hline & $(1)$ & $(2)$ & $(3)$ & $(4)$ & $(5)$ & (6) \\
\hline \multirow[t]{2}{*}{ First child is born lucky (1:yes,0:no) } & & & & & -0.039 & -0.009 \\
\hline & & & & & [0.039] & [0.040] \\
\hline \multirow[t]{2}{*}{ First child is born in an auspicious year for either boys or girls (1:yes,0:no) } & -0.028 & -0.017 & & & & \\
\hline & [0.040] & [0.040] & & & & \\
\hline \multirow[t]{2}{*}{ First child is born in auspicious year for boys only (1:yes,0:no) } & & & -0.022 & -0.002 & & \\
\hline & & & {$[0.037]$} & [0.036] & & \\
\hline \multirow[t]{2}{*}{ Gender of first child (1:boy, $0:$ girl) } & $-0.170^{\star \star \star}$ & $-0.178^{\star \star *}$ & $-0.177^{\star * *}$ & $-0.180^{\star * \star}$ & $-0.177^{\star \star \star}$ & $-0.180^{\star * *}$ \\
\hline & {$[0.037]$} & {$[0.038]$} & {$[0.036]$} & {$[0.037]$} & {$[0.036]$} & {$[0.037]$} \\
\hline \multirow[t]{2}{*}{ Mother's age at time of first birth } & $-0.074^{\star * *}$ & $-0.069^{* * *}$ & $-0.074^{* * *}$ & $-0.069^{* * *}$ & $-0.074^{\star * *}$ & $-0.069^{* * *}$ \\
\hline & {$[0.006]$} & {$[0.007]$} & {$[0.006]$} & {$[0.007]$} & {$[0.006]$} & {$[0.007]$} \\
\hline \multirow[t]{2}{*}{ Father's age at time of first birth } & $-0.021^{* \star *}$ & $-0.017^{* \star *}$ & $-0.021^{* * *}$ & $-0.017^{\star \star \star}$ & $-0.021^{\star \star *}$ & $-0.017^{\star * *}$ \\
\hline & {$[0.006]$} & {$[0.006]$} & {$[0.006]$} & {$[0.006]$} & {$[0.006]$} & {$[0.006]$} \\
\hline \multirow[t]{2}{*}{ Mother's education } & $-0.043^{* * *}$ & 0.003 & $-0.043^{* * *}$ & 0.003 & $-0.043^{* * *}$ & 0.003 \\
\hline & [0.007] & [0.008] & [0.007] & {$[0.008]$} & {$[0.007]$} & {$[0.008]$} \\
\hline \multirow[t]{2}{*}{ Father's education } & $-0.042^{* \star *}$ & $-0.023^{\star \star \star}$ & $-0.042^{\star \star \star}$ & $-0.023^{* \star *}$ & $-0.042^{\star \star \star}$ & $-0.023^{\star * *}$ \\
\hline & {$[0.008]$} & {$[0.008]$} & {$[0.008]$} & {$[0.008]$} & {$[0.008]$} & {$[0.008]$} \\
\hline Time trend (linear and quadratic in year of birth of first child) & yes & yes & yes & yes & yes & yes \\
\hline Commune fixed-effects & no & yes & no & yes & no & yes \\
\hline Observations & 3383 & 3383 & 3383 & 3383 & 3383 & 3383 \\
\hline R-squared & 0.37 & 0.56 & 0.37 & 0.56 & 0.37 & 0.56 \\
\hline
\end{tabular}

Data:VLSS93 and VLSS98

Robust standard errors in brackets, clustered at the commune level

* significant at $10 \%$; ${ }^{* *}$ significant at $5 \%$; ${ }^{* * *}$ significant at $1 \%$

A child is born lucky if he is a boy born in year auspicious for boys, or she is a girl born in a year auspicious for girls 


\section{Table 6: Ex-ante planning versus ex-post horoscope}

\section{PANEL A: Horse race}

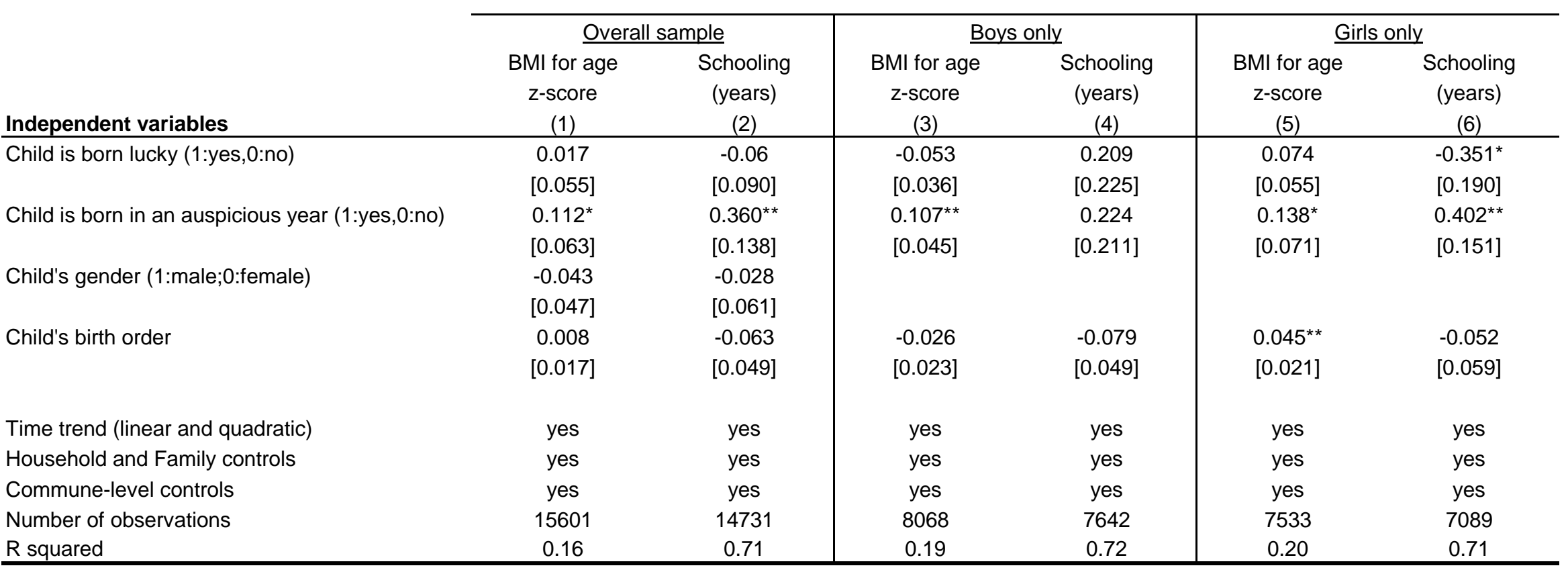

Data:VLSS93 and VLSS98

Robust standard errors in brackets, clustered at the year-of-birth level

* significant at $10 \%$; ${ }^{* *}$ significant at $5 \%$; ${ }^{* * *}$ significant at $1 \%$

Household controls include logarithm of per capita real consumption; family controls consist of family size, parents' education, height, and weight, parents' age at time of first birth

Commune-level controls include commune dummies and logarithm of cohort size

An auspicious year is a year that is auspicious for either boys or girls

A child is born lucky if he is a boy born in year auspicious for boys, or she is a girl born in a year auspicious for girls 


\section{PANEL B: Sample restricted to children born unlucky}

\begin{tabular}{|c|c|c|c|c|c|c|}
\hline \multirow[b]{2}{*}{ Independent variables } & \multicolumn{2}{|c|}{ Overall sample } & \multicolumn{2}{|c|}{ Boys only } & \multicolumn{2}{|c|}{ Girls only } \\
\hline & $\begin{array}{c}\text { BMI for age } \\
\text { z-score } \\
(1)\end{array}$ & $\begin{array}{c}\text { Schooling } \\
\text { (years) } \\
(2) \\
\end{array}$ & $\begin{array}{c}\text { BMI for age } \\
\text { z-score } \\
\text { (3) }\end{array}$ & $\begin{array}{c}\text { Schooling } \\
\text { (years) } \\
(4) \\
\end{array}$ & $\begin{array}{c}\text { BMI for age } \\
\text { z-score } \\
(5)\end{array}$ & $\begin{array}{c}\text { Schooling } \\
\text { (years) } \\
(6) \\
\end{array}$ \\
\hline \multirow[t]{2}{*}{ Child is born in an auspicious year (1:yes, $0:$ no) } & $0.119^{*}$ & $0.310^{* *}$ & $0.092^{* *}$ & $0.283^{* *}$ & $0.138^{*}$ & $0.389^{* *}$ \\
\hline & [0.062] & {$[0.135]$} & {$[0.040]$} & [0.093] & {$[0.068]$} & {$[0.150]$} \\
\hline \multirow[t]{2}{*}{ Child's gender (1:male,0:female) } & 0.020 & -0.182 & & & & \\
\hline & [0.053] & [0.109] & & & & \\
\hline \multirow[t]{2}{*}{ Child's birth order } & $0.038^{* *}$ & -0.075 & 0.015 & 0.003 & $0.055^{\star *}$ & $-0.143^{*}$ \\
\hline & {$[0.016]$} & [0.065] & [0.038] & {$[0.077]$} & [0.024] & [0.067] \\
\hline Time trend (linear and quadratic) & yes & yes & yes & yes & yes & yes \\
\hline Household and Family controls & yes & yes & yes & yes & yes & yes \\
\hline Commune-level controls & yes & yes & yes & yes & yes & yes \\
\hline Number of observations & 9503 & 9008 & 4149 & 3942 & 5354 & 5066 \\
\hline R squared & 0.18 & 0.69 & 0.25 & 0.72 & 0.22 & 0.70 \\
\hline
\end{tabular}

\section{Data:VLSS93 and VLSS98}

Robust standard errors in brackets, clustered at the year-of-birth level

* significant at $10 \%$; ${ }^{* *}$ significant at $5 \%$; ${ }^{* * *}$ significant at $1 \%$

Household controls include logarithm of per capita real consumption; family controls consist of family size, parents' education, height, and weight, parents' age at time of first birth

Commune-level controls include commune dummies and logarithm of cohort size

An auspicious year is a year that is auspicious for either boys or girls

A child is born lucky if he is a boy born in year auspicious for boys, or she is a girl born in a year auspicious for girls 
PANEL C: Sample restricted to girls born lucky in an inauspicious year for boys or born unlucky in an auspicious year for boys

\begin{tabular}{|c|c|c|c|c|}
\hline \multirow[b]{4}{*}{ Independent variables } & \multirow{2}{*}{\multicolumn{4}{|c|}{ Dependent variables }} \\
\hline & & & & \\
\hline & $\begin{array}{l}\text { BMl for age } \\
\text { z-score }\end{array}$ & $\begin{array}{l}\text { Schooling } \\
\text { (years) }\end{array}$ & $\begin{array}{l}\text { Height for age } \\
\text { z-score }\end{array}$ & $\begin{array}{c}\text { Weight for age } \\
\text { z-score }\end{array}$ \\
\hline & $(1)$ & & (3) & $(4)$ \\
\hline Girl is born in an auspicious year boys (1:yes,0:no) & {$[0.056]$} & {$[0.070]$} & {$[0.070]$} & {$[0.067]$} \\
\hline \multirow[t]{2}{*}{ Girl's birth order } & 0.016 & $-0.059^{* *}$ & $-0.040^{* *}$ & -0.017 \\
\hline & {$[0.014]$} & {$[0.024]$} & {$[0.015]$} & [0.018] \\
\hline Time trend (linear and quadratic) & yes & yes & yes & yes \\
\hline Household and Family controls & yes & yes & yes & yes \\
\hline Commune-level controls & yes & yes & yes & yes \\
\hline Number of observations & 4889 & 4288 & 4903 & 4904 \\
\hline R squared & 0.03 & 0.53 & 0.01 & 0.01 \\
\hline
\end{tabular}

Data:VLSS93 and VLSS98

Robust standard errors in brackets, clustered at the year-of-birth level

* significant at $10 \%$; ** significant at $5 \%$; *** significant at $1 \%$

Household controls include logarithm of per capita real consumption; family controls consist of family size, parents' education,

height, and weight, parents' age at time of first birth

Commune-level controls include commune dummies and logarithm of cohort size

A child is born lucky if he is a boy born in year auspicious for boys, or she is a girl born in a year auspicious for girls 


\section{Table 7: More on the "Marginal Child": Family Fixed-Effect Estimations}

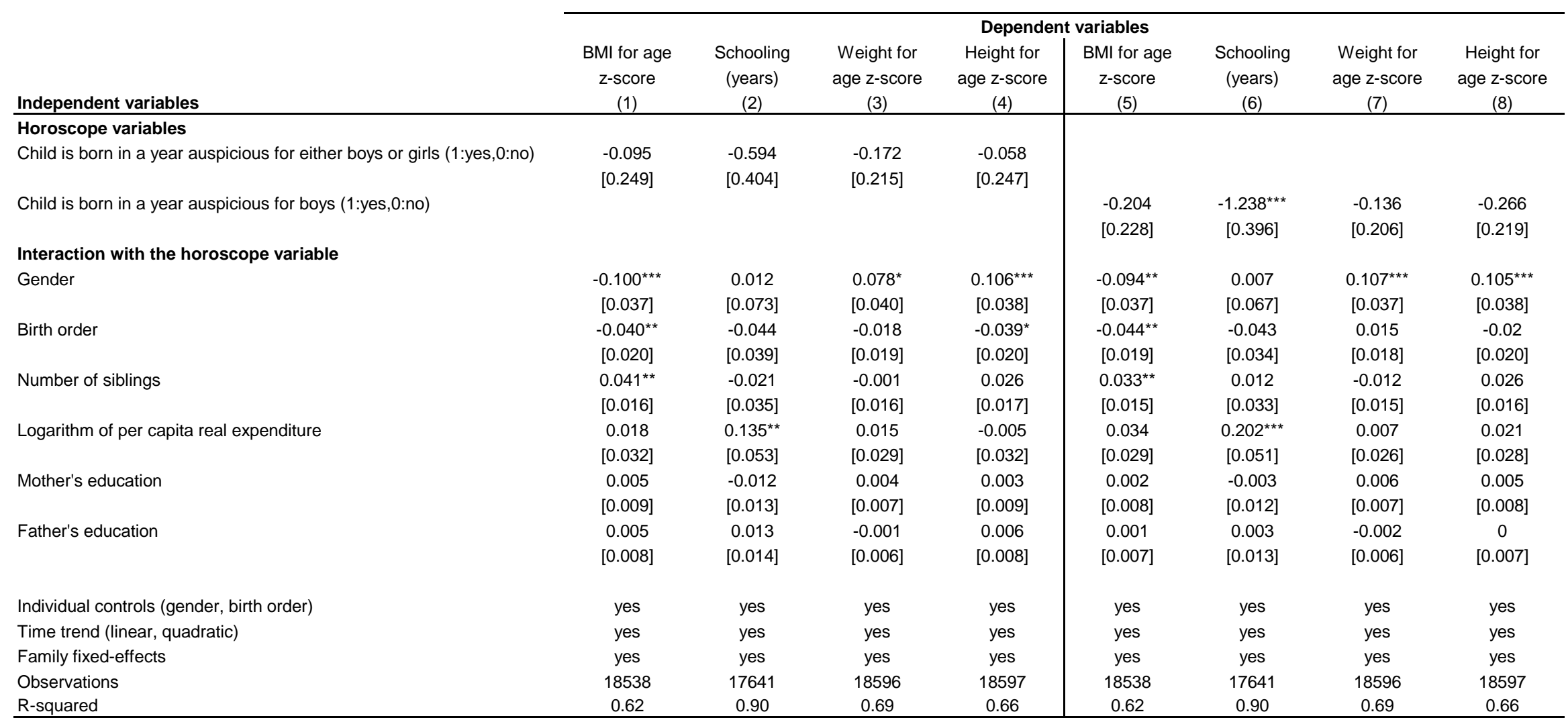

\section{Data from VLSS93 and VLSS98}

Standard errors in brackets, clustered at the commune-level

${ }^{*}$ significant at $10 \%$; ** significant at $5 \%$; ${ }^{* * *}$ significant at $1 \%$ 


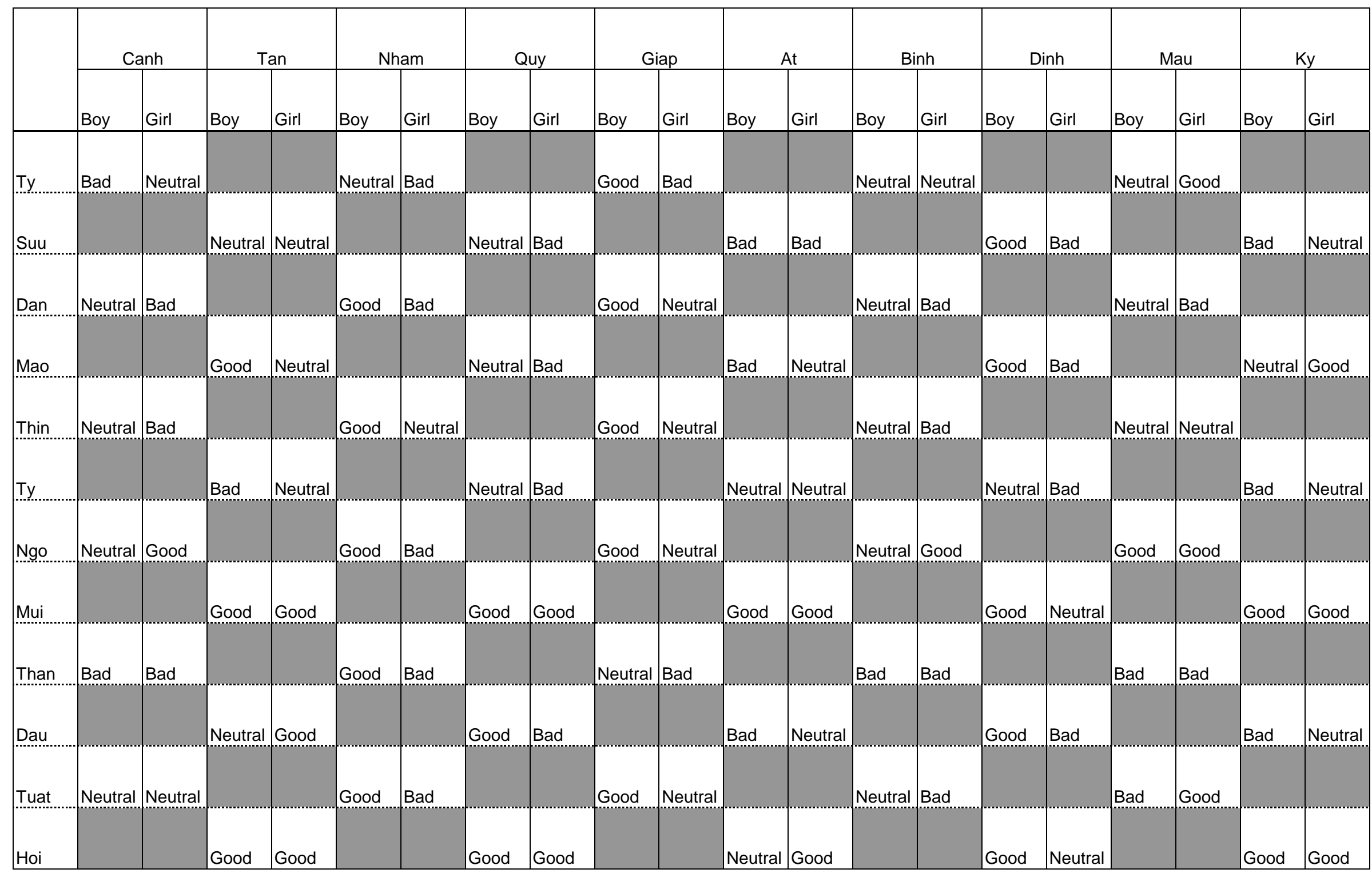

Data Source: Informal interviews with a fortune teller in Vietnam, double-checked with Lich Van Nien (Nha Xuat Ban Dan Toc Publishing house, 1999), and http://www.tuviglobal.com. 